\title{
FACTORS AFFECTING THE CAREER DEVELOPMENT OF STAFF IN THE BANKING SECTOR: A CASE STUDY OF A PRIVATE BANK OF SRI LANKA
}

\author{
Giragama K. W. K.M.W ${ }^{1}$, Sooriyabandara W.M.S.L.H. ${ }^{2}$ \\ ${ }^{1}$ School of Business Management, Cardiff Metropolitan University, (UK) \\ ${ }^{2}$ Department of Business Management, International College of Business and Technology
}

\begin{abstract}
Sri Lankan banking industry is playing a major role in the Sri Lankan economy and the perception to get a banking employment is so high in Sri Lankan mind sets due to its' prestigious social status within the country. However, after getting involved in to the employment as a "Banking assistant" there are several aspects a banking employees' life cycle would affect due to the highly competitive Sri Lankan banking sector. This study is an attempt to investigate the career development of staff in the private banking sector of Sri Lanka. A case study approach has been selected based on a Sri Lankan leading private sector bank which consisted 159 branch network all over the island. The main aim of this study is to determine the significant factors which effect the career development of employees in XYZ banking Plc. Seven independent variables namely; Training, Organizational goals, Career education, empowerment, individual attitudes, individual career mapping, self-appraisal were selected from main two areas such as Organizational Career planning and Individual career planning to determine the relationships with employee career development. Results were produced by 93 respondents out of 158 sample size. Study results revealed Training, Organizational Goals, Career Education, Empowerment and self-appraisal are significant factors for the career development. Moreover, results showed that Training, Career mapping, Individual attitudes have significant differences between groups in terms of "Gender" and Training, Organizational Goals, career education, Empowerment, Individual attitudes, Career Mapping, Self-appraisal have a significant difference between groups in terms of "Age".
\end{abstract}

Keywords: career development, banking industry, private banking employees

\section{Introduction}

\section{Background of the Study}

"Bank" is a licensed financial service provider. In Sri Lanka there are 25 licensed Banks, competing with each other in a highly competitive financial environment.

The taken case is from a Sri Lankan leading private bank which consist an employee base of 2,947 and has opened 159 branches around the country.

The bank was targeting to increase the number of branches to 225, and to upgrade its position from the fourth largest commercial bank to the third largest commercial bank in Sri Lanka by the end of the year 2017.

However, in this journey to achieve its corporate goals decided by the Management, Board of Directors, and stakeholders it is evident that the bank requires capable, competent and efficient employee's/staff carder.

In order to retain such staff carder any organisation would favor to possess only the skilled employee base, and to retain the preferred carder compensations need to be given and the main attraction is career development or promotions to higher grades. 
Therefore, the employees need to understand the requirements of the organization in order to be required by the organization and embrace career development opportunities.

The selected private bank was undergoing a substantial strategic change, as they were planning to increase the number of branches to 225 from the present number of 159 , and grow other figures in profitability, asset base, deposits and advances.

At this juncture a few internal issues were obvious and to name a few are high staff turnover, new employees were recruited to higher positions, stagnation of staff in same grades for a longer period, high number of staff in lower middle grade called "Sub Officer", Pressure from trade unions towards Management, Aged employees in lower grades, high amount of staff grievances, Performance standard of newly promoted staff etc. So, it is obvious that there is a gap in staff requirement and the bank's perception on career development.

Therefore, this research was carried out as a case study to identify the factors that affect the career development of banking employees.

\section{Research Problem Identification}

\section{Symptoms of the Problem}

On having interviews/ discussions, the issues that were revealed by employees of the selected private bank employed in Senior Management, Middle level management, operational staff and the issues identified on perusal of the bank's Annual report are as follows;

- Staff turnover is higher comparative to the trade norm

- number of staff in the lower grade category is higher

- The stagnation in the same grade is lengthy

- Trade unions induce pressure towards the management to adhere to the promotions policy agreed by the staff union and the management when promotions are considered.

- Further the Private bank's management perception on the new staff appointments are not met as revealed by the discussions held with some of the top management personnel's

- Age of the employees

- grievances are not handled at the best effort basis

- Staff in the grade considered to be the highest position of other (lower) staff category is high as justified by the Annual Report of the bank.

\section{Defining Research Problem}

"There are some significant factors affecting the career development of the employees in the private Bank."

The employees of the private bank in Sri Lanka perform with a significant variance between each other. The study targets towards determining the factors that would impact on Employee's career Development in the private bank. 


\section{Research Question}

What are the Reasons to have significant variances of the private bank Employee's career Development?

\section{Objectives of the Study}

\section{Main Objective}

- To determine the significant factors which affect the career development of employees in the private bank.

\section{Sub-Objectives}

- To determine the difference of Employee Career Development in terms of Demographic Factors.

- To give recommendations to the private bank for the factors that affects the career development of employees in the private bank.

\section{Significance of the study}

- The findings of this study will be important for the Banks on improvement of their employee's career development

- This will be important for the private bank's higher management, and Region Managers/ Area Manager for the improvement of their employee's career development

- This will be important for the researchers or any reader for their career development

- This can be used by another researcher for further study on employee's career development

\section{Limitations of the Study}

On a research of this nature the following can be identified as limitations

- Whether the target group submitted their honest opinion

- Time constraints on collection of data

- Whether all questionaries' will be completed and returned to the researcher

- Whether the Management of the bank will allow the researcher to carry out/ obtain details on the bank?

- Whether this can be generalized to all the banks or organizations?

- This research is a sensitive matter, and obtaining details from the management and HR may have constraints.

\section{Critical Review of Literature}

The literature similar to the research problem was reviewed, and discussed. The research problem is arisen due to the gap of the factors that affect the career development of employees in the private Bank.

Literature was reviewed in 17 previous case studies, developed in many different countries such as Africa, Pakistan, Indonesia, India, Australia, U.K. 
The factors identified to affect the career development of employees in previous literature were mainly divided in to "Organizational", and "Individual".

Further many models used in the previous studies were identified and the following were elaborated for this research.

\section{CONSUMER}

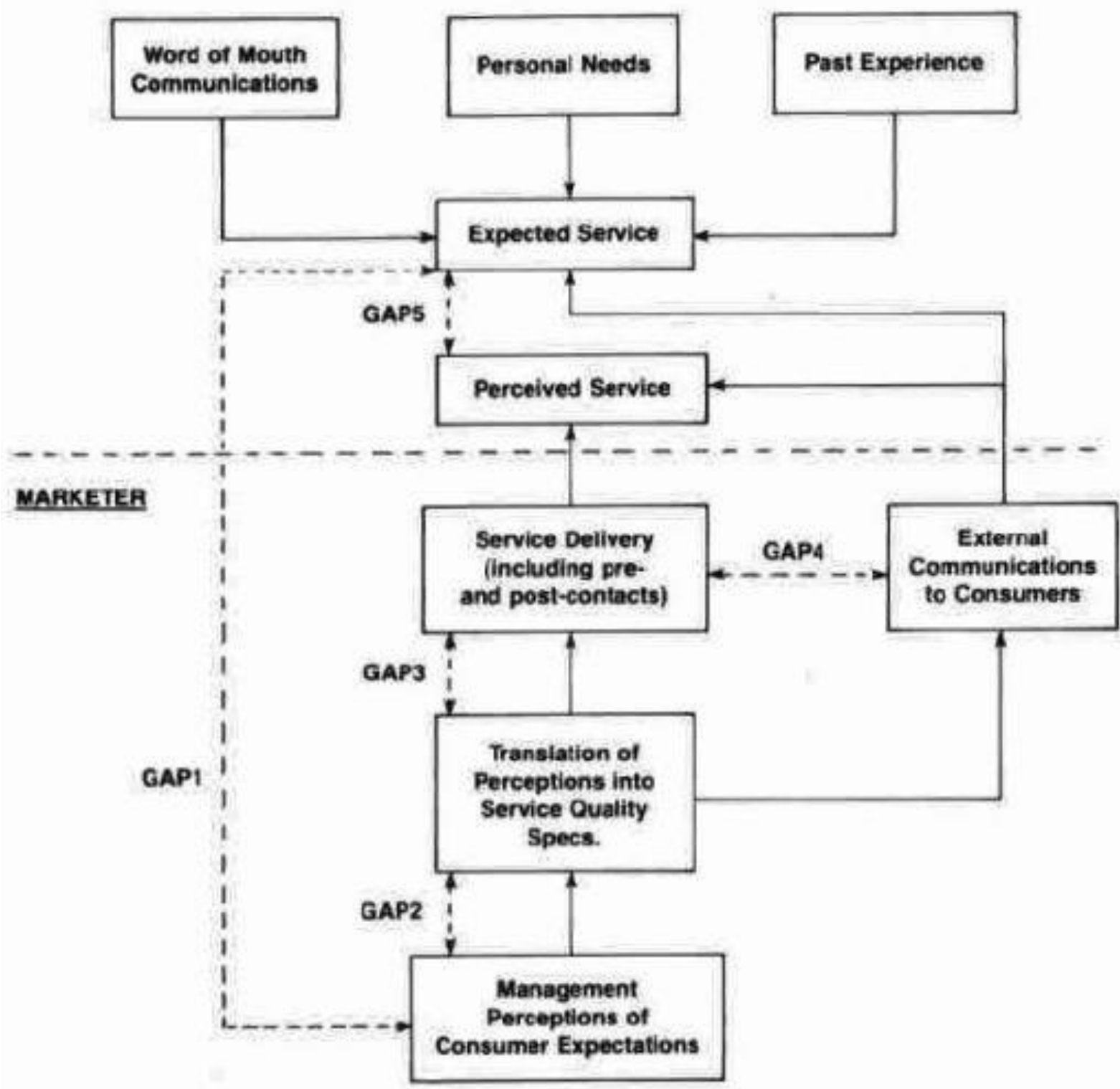

Figure 1: SERVQUAL Model (Parasuraman et al (1988)

The above discusses five gaps

- Gap 1 is the gap between what the customer expects and what the company's management thinks customers expect.

- Gap 2 is the gap that occurs when management fails to design service standards that meet customer expectations. 
- Gap 3 occurs when the company's service delivery systems - people, technology and processes - fail to deliver to the specified standard

- Gap 4 occurs when the company's communications with customers promise a level of service performance that people, technology and processes cannot deliver.

- Gap 5 - The gap between the customer expectation, and the customer perception, and this gap was mainly focused.

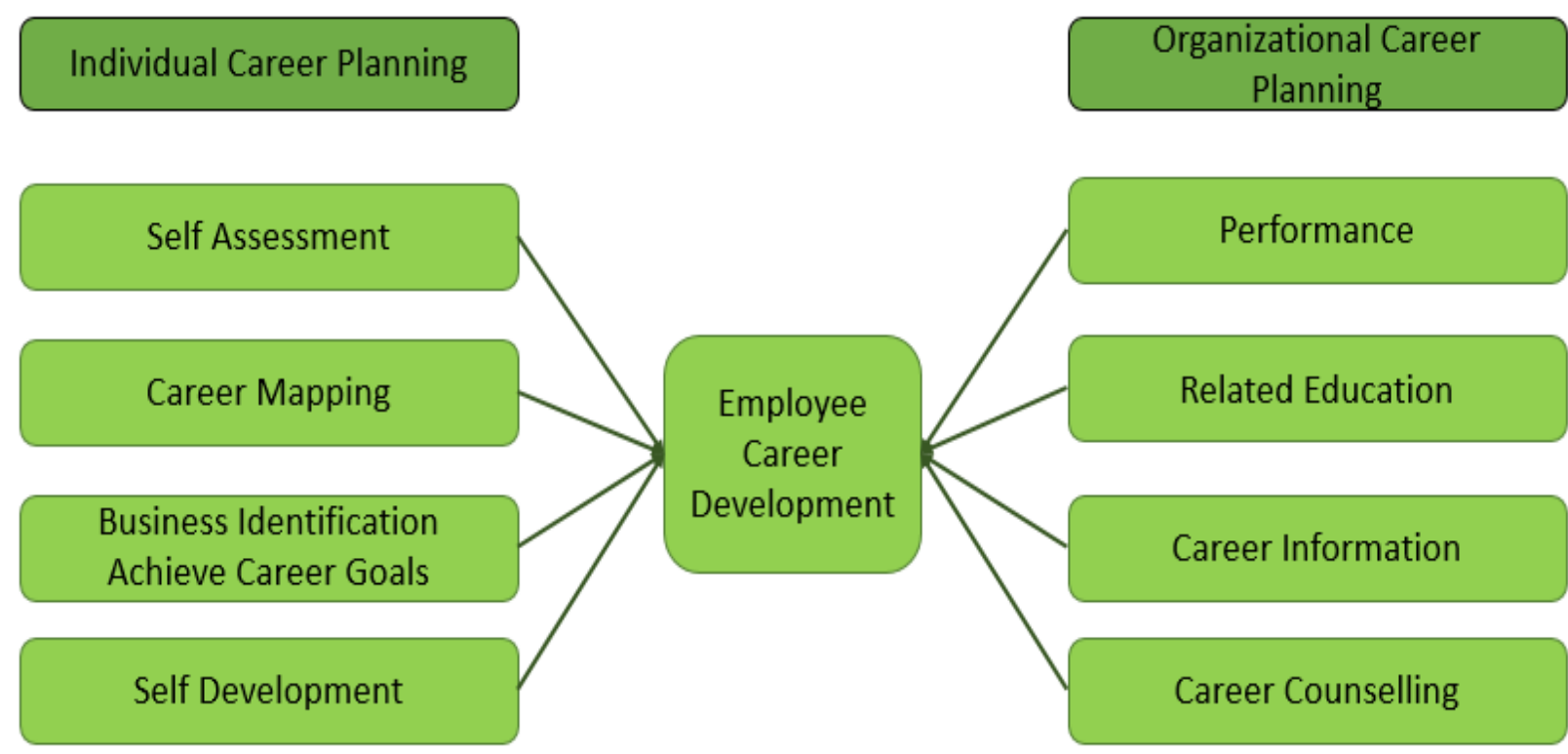

Figure 2 : Model used in the case study of Factors Affecting Career Development of Employees in Secretariat office of Samarinda - Randy S et al (2005)

In this model the factors were divided in to Individual and Organizational career planning, and each was evaluated.

These studies reveal overlapping independent variables - training, organizational goals, career education, performance assessment, empowerment in the point of organizational context, and individual attitudes, career mapping, self-appraisals in the point of individual context. Therefore, in this research same independent variables are considered, and the dependent variable is identified to be the career development of the selected private bank's employees.

Therefore, on review of the above the following conceptual framework was developed for this research. 


\section{Conceptual Framework}

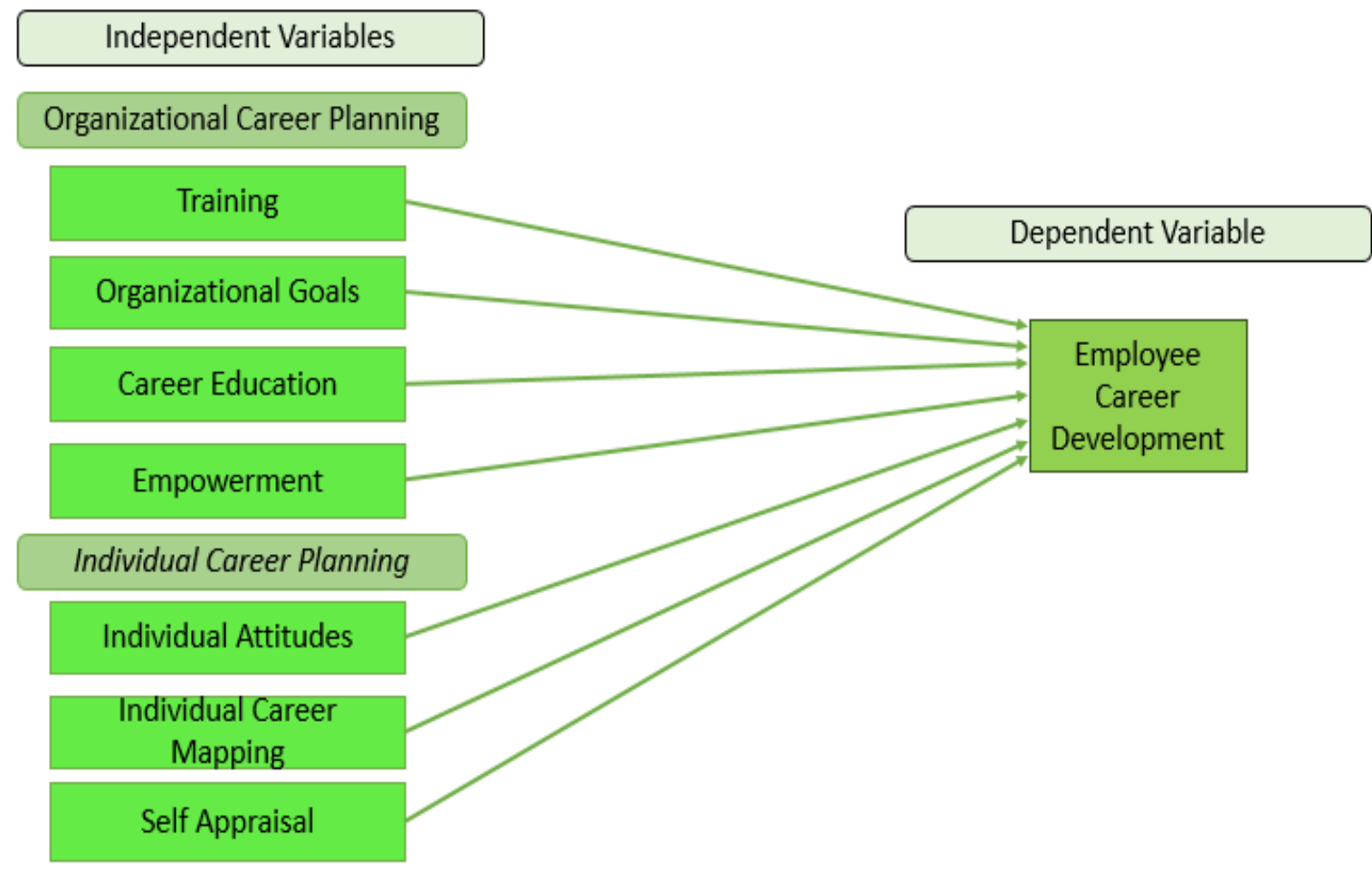

Figure 3: Conceptual Framework

According to the previous literature the dependent and independent variables were defined as follows.

Table 1 - Literature Review

\begin{tabular}{l|l|l}
\hline Variable & Literature & Author/s \\
\hline Training & $\begin{array}{l}\text { Methods that are applied to provide new recruits } \\
\text { with the skills needed to perform their duties }\end{array}$ & $\begin{array}{l}\text { Desseler } \\
(2006)\end{array}$ \\
\hline $\begin{array}{l}\text { Organizational } \\
\text { Goals }\end{array}$ & $\begin{array}{l}\text { A goal is a statement of a desired future an } \\
\text { organization wishes to achieve }\end{array}$ & $\begin{array}{l}\text { Randy et. al } \\
(2005)\end{array}$ \\
\hline $\begin{array}{l}\text { Career } \\
\text { Education }\end{array}$ & $\begin{array}{l}\text { Career education services provide an opportunity } \\
\text { for people of all ages and backgrounds to learn the } \\
\text { skills, strengths and potential for various types of } \\
\text { work, and chose a job that suits the purpose and } \\
\text { personality of employee }\end{array}$ & $\begin{array}{l}\text { Notoatmodjo } \\
(2009)\end{array}$ \\
\hline Empowerment & $\begin{array}{l}\text { Increase the capacity of the employee and also } \\
\text { provide freedom of work which will build the } \\
\text { confidence among employees }\end{array}$ & $\begin{array}{l}\text { Abdul et. al } \\
(2011)\end{array}$ \\
\hline $\begin{array}{l}\text { Individual } \\
\text { Attitudes }\end{array}$ & $\begin{array}{l}\text { Mind set or tendency to act in a particular way due } \\
\text { to both an individual's experience and } \\
\text { temperament. }\end{array}$ & $\begin{array}{l}\text { Allport } \\
(1939)\end{array}$ \\
\hline
\end{tabular}




\begin{tabular}{l|l|l}
\hline $\begin{array}{l}\text { Individual } \\
\text { Career } \\
\text { Mapping }\end{array}$ & $\begin{array}{l}\text { A process to describe the career prospects of an } \\
\text { employee, including an explanation of the level of } \\
\text { employee readiness to assume certain positions. }\end{array}$ & $\begin{array}{l}\text { Randy et al } \\
(2005)\end{array}$ \\
\hline Self-Appraisal & $\begin{array}{l}\text { Help employees to determine career Plans in } \\
\text { accordance with the employee needs and interests } \\
\text { of the organization. }\end{array}$ & $\begin{array}{l}\text { Siagian } \\
(2001)\end{array}$ \\
\hline $\begin{array}{l}\text { Career } \\
\text { Development }\end{array}$ & $\begin{array}{l}\text { Of great importance to both individual employee } \\
\text { and the organization. }\end{array}$ & $\begin{array}{l}\text { Armstrong } \\
(2001)\end{array}$ \\
\hline
\end{tabular}

\section{Hypothesis Formulation}

Alternative Hypotheses (Ha) and Null Hypotheses (Ho) were developed for all seven independent variables to test with the empirical findings.

\section{Operationalization of Variables}

"Operationalization" compromises how the variables are to be measured. (Veal, 2006). In the table given in Annex I, the operational components are explained, and the measurement of each variable are detailed. A questionnaire designed for the study was used as a tool for the empirical investigation

\section{Methodology}

\section{Population}

The targeted population was the total number of employees amounting to 2974 , and the ideal sample size was selected by "Sample size survey system".

158 questionnaires were randomly distributed, and 93 were collected on time, and this satisfied the minimum requirement of samples.

\section{Sampling Method}

The researcher has used stratified random sampling methods to collect data.

\section{Data Collection}

Data was collected by way of distributing questionnaire. Demographic data were collected by simple structured questions, while the data regarding the variables were graded using "likert scale" that had five range of answers from "strongly agree to strongly disagree".

\section{DATA Analysis}

The gathered data were analyzed under two main statistical data analysis such as "Descriptive statistics" which gives more understanding regarding gathered data and "Inferential statistics" to test the relationship between independent variables and dependent variable. 
The Findings were as follows;

Main Objective achievement:

To determine the significant factors which affect the career development of employees in the private bank.

Training, Career mapping, Individual Attitudes have significant difference between Groups in terms of "Gender". When considering the Equal variances not assumed value in "Sig. (2-tailed)" the value is less than 0.05 which indicates the variables are significant.

Sub-Objectives achievements:

Sub Objective 01:

\section{To determine the difference of Employee Career Development in terms of Demographic Factors}

Training, Career mapping, Individual attitudes have significant differences between groups in terms of "Gender" and Training, Organizational Goals, career education, Empowerment, Individual attitudes, Career Mapping, Self-appraisal have a significant difference between groups in terms of "Age".

\section{Conclusion}

In conclusion of the study it can be identified that according to selected context significant factors are Training, Organizational goals, Career Education, Empowerment, and self-appraisal.

These results are similar with past studies done by Rande S et al (2015), in Samarinda and it was identified that Career Counselling, Performance Appraisal and Career Mapping has significant relationship with Career Development.

On the research carried out by Marinka A C T et al (2006) also had resulted that Motivation, Position, Career support, Ambition has significant impact on career development.

Results showed that Training, Career mapping, Individual Attitudes have significant difference between Groups in terms of "Gender" and it is confirmed by Equal variances not assumed value in "Sig. (2-tailed)" since the value is less than 0.05 .

Furthermore, results highlighted that Training, Career mapping, Individual attitudes have significant differences between groups in terms of "Gender" and Training, Organizational Goals, career education, Empowerment, Individual attitudes, Career Mapping, Self-appraisal have a significant difference between groups in terms of "Age".

These results are similar with the past researches, and could be said to have that the factors appear to be connected to findings of previous findings.

Sub Objective 2:

\section{Recommendations}

Recommendations were given by descriptive statistical analysis. Respondents agreed that Training is considered to be an important factor in the private bank, but there were respondents who disagreed or 
stayed neutral, hence it is evident that all the respondents does not agree that Training is recognized by the bank for their career development. On Hypotheses Analysis "Training" was identified as a factor that has a significance on Career Development.

Therefore, it is recommended to the bank to give more recognition for "staff Training".

Respondents agreed on the statements relating Organizational goals at a majority level, but they were mainly neutral on effective communication of Organizational goals. There were disagreements also. On Hypotheses analysis it was identified, that "Organizational Goals" has a significant impact on "Career Development of the bank Employees." Therefore, it is recommended to the bank to focus on communication of Organizational Goals more effectively to employees, and to take measures to bridge the gap in taking flexible approach in issues arising between work and family, and to focus on improving the work-area design.

Respondents agreed on the statements of Career education, but there was considerable amount of "Neutral" remark, and disagreements. Hypotheses analysis showed that Career Education has a significant relationship with "Career Development" of the bank employees.

It is recommended that the bank should pay more emphasis on career mentoring/coaching by way of appointing mentors and having discussions monthly, and improve acknowledging when staff performs well, by way of issuing commendation letters, and should provide job information down the line. It is noteworthy that majority of respondents were in other grade category and they need to be given these additional facilities.

Respondents on majority agreed that they are "Empowered" when performing their job, but there were significant "Neutral" remarks, and disagreements. Hypotheses analysis demonstrated that "Empowerment" has a significant relationship with "Career Development".

Therefore, it is recommended that the bank should encourage employees to carry out their job by allowing more freedom in performing their duties. Respondents on majority agreed with the statements on "Individual Attitudes", but were "Neutral" statements and disagreements. On Hypotheses analysis "Individual Attitudes" did not have a significant relationship with "Career Development".

Respondents agreed on majority with the statements on "Individual Career Mapping" and "Neutral" and disagreements were lower comparatively to other factors. On Hypotheses analysis it was identified that there is no significant relationship between "Individual Career Mapping" and "Career development" of the bank Employees.

Respondents were in agreement on statements in "Self-appraisal", but there were "Neutral" remarks, and disagreements. Hypotheses analysis demonstrated that "Self-Appraisal" has a significant relationship with "Career Development".

Therefore, it is recommended that the bank should focuses on "Self-Appraisal" of SBK employees by way of giving feed-back on their career developmental needs etc. On analyzing gender wise independent t-tests it was found that Training, Career Mapping, Individual Attitudes, had a difference with the "Gender", while there was no difference on Organizational Goals, Empowerment and self-Appraisals. Therefore, it is recommended to consider Gender on designing Training programs, career mapping and considering Individual Attitudes.

Results of one-way Anova test proved that Training, Organizational Goals, Career Education, Empowerment, Individual Attitudes, Career Mapping, Self-Appraisals had no difference with "Age", "Designation in the bank", "Length of service in the bank", "Marital status", "Number of Children "and "Length of period in the current position". Therefore, it is recommended that there should not be any discrimination when setting Organizational Goals, Career educational programs, on allowing "Empowerment", considering "Individual Attitudes", "career 
Mapping", and "self-appraisals" on these demographic factors. According to one-way Anova testing Highest qualification differs on "Career Education", but has no difference on "Training", "Organizational Goals", "Empowerment", "Individual Attitudes", "Career Mapping” and Self-Appraisals. Hence it is recommended that when designing Career Educational aspects to consider Qualification level of Employees.

\section{Recommendation for future study}

This research was carried out on Career Development of Employees of the bank, and it is suggested to carry out further researches on other local private banks, Government Banks, International banks and compare results for further elaboration.

This research was on career development of the bank Employees, and same could be extended to other financial companies, Multinational companies and Higher Educational Institutes. This research has considered Demographic factors such as Age, Gender, Designation, Length of service, marital status, Length of service in the current position and highest qualification and Independent variables namely Training, Organizational goals, Career Education, Empowerment, Individual Attitudes, Individual Career Mapping and Dependent Variable Career Development. It is recommended to carry out further research on each of Independent variables against the Dependent variable for further elaboration as to find the most significant factors that affect career development of employees of the bank.

\section{References}

Abdul, H and Aamer, W., (2011). Employee Development and its Affects on Employee Performance A Conceptual Framework. International Journal of Business and Social Science. 2(13): 224-228

Allport, G. W. (1935). Attitudes. In Murchison C. (Ed.), Handbook of social psychology (pp. 798-844). Worcester, MA: Clark University Press.

Ardeniji, A, A. and Osibanjo, A, O., (2012). Human Resource Theory and Practice. Pumark Nigeria Limited, Lagos p 437.

Armstrong, M., (2001) Human Resource Management Practice handbook, 8th ed. London: Kegan Page Ltd

Baruch, Y. (2003). Transforming careers-from linear to multidirectional career paths: Organizational and individual perspective. Career Development International, 9(1), 58-73

Baruch, Y., \& Rosenstein, E. (1992). Career planning and managing in high tech organizations. International Journal of Human Resource Management, 3(3), 477-496.

Bezuidenhout M,Grobler A and Rudolph, E.C (2013). The utilization of a Career Conversation Framework Based on Schin's Career Anchors Model.University of South Affrica, South Affrica: 1-10

Bollen, K.A. \& Long, J.S. (1993) [Eds.] Testing structural equation models. Newbury Park, California: Sage, 136-162.

Browne, M.W. \& Cudeck, R. (1993). Alternative ways of assessing model fit.

Central Bank Sri Lanka, (2014).

Coetzee, M, and Schreuder, D. (2009). Using the Career Orientations Inventory for Measuring Internal Career orientations in the south African organizational context. South African Journal of Industrial Psychology. 35(1): 1-13.

Creative Research System, (2016). Sample Size Calculator. [Online] Available at: http://www.surveysystem.com/sscalc.htm. [Accessed on 2/02/2016]

Delaney, J. T. and Huselid, M. A. (1996). The impact of human resource management practices on perceptions of organizational performance. Academy of Management Journal, 39(4), 949-970.

Dessler, G. (2006). A framework for human resource management. New Jersey: Pearson/Prentice Hall

Egan, G. (1975). The skilled Helper. A Problem- Management and opportunity- Development Approach to Helping. Monterey: Brooks/Cole 
Feldman, D, C, and Bolino, M, C., (2001) Careers within Careers: conceptualizing the nature of career anchors and their consequences. [Research Paper] University of south Carolina

Fey, C. F., Pontus, E., and Ingmar, B. (1999). Effective human resource management practices for foreign firms in Russia. Organizational Dynamics, 28(2), 69-80.

Glasser, W. (1965). Reality therapy. New York: Evanston and London: Harper \& Row

Graham, H, T., \& Bennett, R., (1995). Human Resource Management, 8th Ed, London: The M \& E Handbook series, Longman Group U K Ltd.

Gutteridge T. G, Zandy B. Leibowitz, Jane E. Shore, (1993) Published by Pfeiffer, ISBN 10: 1555425267 / ISBN 13: 9781555425265 Organizational Career Development: Benchmarks for Building a World-Class Workforce (Jossey-Bass Management)

Hackman, J.R. (1986). The psychology of self-management in organizations. In Pallack, M.S.; Perloff, R.O. (eds). Psychology and work: productivity, change and employment. Washington DC: American Psychological Association

HSBC, (2014). Annual Report 2014. Colombo: HSBC PLC

Ivancevich, J. M. (2001). Human Resource Management. (8th Ed.). New York: The McGraw-Hill Companies, Inc.

Jöreskog, K. and Sörbom, D. (1993), Structural Equation Modeling with the SIMPLIS Command Language. Chicago, IL: Scientific Software International Inc.

Jukova M. and Konstantin, K. (1998). From a personnel department in Soviet Union to a human resource department in Russia. People and Labour, 8, 88-91.

Koch, J., and McGrath, R. G. (1996). Improving labour productivity - human resource management policies do matter. Strategic Management Journal, 17, 335-354.

Kotler, P., Armstrong, G., Saunders, J. and Wong, V. (1999), Principles of Marketing. Prentice Hall Europe, New Jersey: Upper Saddle River,

Kozybsky, A. (1994). Science and Sanity. Lakeville: Institute of General.

Marinka A, C, T. (2016) Career Competencies for Career Success[Online] available at: https://www.questia.com/library/journal/ [Accessed on 20/2/2016]

Mishra, B. and Sachan, D., (2012) Career Management: A Key Driver of Performance and Productivity. International Journal of Management research and Review. 2(8): 1334- 1341.

Mondy, R,W., and Noe, R, M., (2005). Human Resource Management. 9th Edition. Massachusetts: Pearson Education, Inc.

Notoatmodjo, S. (2009). Pengembangan Sumber Daya Manusia. Jalarta: Rineka Cipta

Parasuraman A, Zheitmal V, A, and Berry L, L. (1998) SERVQUAL: a multipleitem scale for measuring consumer perceptions of service quality. Journal of Retailing. 64(1): 12-40.

Penna consulting PLC(2013) Self Appraisal journal article [Online] available at http://www.acdp.pt/wpcontent/uploads/2013/07/Self-appraisal.pdf [Accessed on 20/02/2016]

Parasraman, A, Berry,L.L,Zaithamal,V.A, (1988) SERVQUAL: A Multiple Item Scale for measuring Consumer Perceptions of Service Quality [Online] available at http://areas.kenanflagler.unc.edu/Marketing/FacultyStaff/zeithaml/Selected\%20Publications/SERVQUAL

[Accessed on 26/02/2016]

Rande, S., Yunus, R., Jamaluddin, A., and Zacharias, T., (2015). Factors Affecting Career Development of Employees in Secretariat Office of city Samarinda. International Scientific and Technology research. 4(3): 9399

Rogers, C, R,. (1961) On Becoming a Person - A therapist`s View of Psychotherapy. 2London: Constable.

Rue, L, W., and Byars, L, L., (2004). Supervision: Key Link to Productivity. $8^{\text {th }}$ ed. New York: McGrawHill/Irwin

Sarah, M, K, N, M, (2010). Career Development and staff motivation in the banking industry: A case study of Bank of Uganda. [Research Paper] Makerere University.

Seylan Bank, (2014) Strategic Plan. Colombo: Seylan PLC 
Giragama K. W. K.M.W, Sooriyabandara W.M.S.L.H / Factors Affecting the Career Development of Staff in.....

Seylan Bank, (2014). Annual Report 2014. Colombo: Seylan Bank PLC

Siagian, S, P., (2003). Manajemen Sumber Daya Manusia. Cetakan Kesepuluh. Jakarta: Bumi Aksara.

Sussie L, P., and Hall L, M., (2005). in Developmental career Coaching” p6, 7, 22, 18,

Terpstra, D. E., \& Rozell, E. J. (1993). The relationship of staffing practices to organizational level measures of performance. Personnel Psychology, 46: 27-48.

Wilensly, H, L., (1961). Careers life style and social Integration. International social science Journal. 12(1): 553-558 
Annexure I

\begin{tabular}{|c|c|c|c|}
\hline Concept & Definition of the concept & Operational Component & Measuring Scale \\
\hline Designation & $\begin{array}{l}\text { Position held by the respondent at } \\
\text { SBK }\end{array}$ & Designation in Seylan Bank PLC & Nominal Scale \\
\hline Age & The age of the respondent & Age & Interval Scale \\
\hline $\begin{array}{l}\text { Length of } \\
\text { service }\end{array}$ & $\begin{array}{l}\text { Number of years the respondent } \\
\text { has served in the current grade }\end{array}$ & Length of Service in Seylan Bank PLC & Nominal Scale \\
\hline Gender & $\begin{array}{l}\text { Refers to the gender of the } \\
\text { respondents }\end{array}$ & Gender & Nominal Scale \\
\hline Marital status & $\begin{array}{l}\text { Whether the respondent is single, } \\
\text { married, separated or widowed }\end{array}$ & Marital Status & Nominal Scale \\
\hline $\begin{array}{l}\text { Number of } \\
\text { Children }\end{array}$ & $\begin{array}{l}\text { How many siblings the respondent } \\
\text { have }\end{array}$ & Number of Children & Nominal Scale \\
\hline $\begin{array}{l}\text { Length of } \\
\text { period in } \\
\text { current position }\end{array}$ & $\begin{array}{l}\text { Number of years the respondent } \\
\text { has served in the current position }\end{array}$ & Length of period in the current position & Nominal Scale \\
\hline $\begin{array}{l}\text { Highest } \\
\text { Qualification }\end{array}$ & $\begin{array}{l}\text { Highest educational level of the } \\
\text { respondent }\end{array}$ & Highest Qualification & Nominal Scale \\
\hline \multirow{3}{*}{ Training } & \multirow{3}{*}{$\begin{array}{l}\text { Refers to grooming staff for better } \\
\text { performance/ results }\end{array}$} & $\begin{array}{l}\text { I feel that SBK values me more after } \\
\text { Training }\end{array}$ & Ordinal Scale \\
\hline & & $\begin{array}{l}\text { SBK provides opportunity to grow and } \\
\text { learn after training }\end{array}$ & Ordinal Scale \\
\hline & & $\begin{array}{l}\text { I see my current position as a training } \\
\text { grounds for another organization }\end{array}$ & Ordinal Scale \\
\hline \multirow{3}{*}{$\begin{array}{l}\text { Organizational } \\
\text { Goals }\end{array}$} & \multirow{3}{*}{$\begin{array}{l}\text { Refers to the goals set by the } \\
\text { organization to achieve } \\
\text { organizational targets }\end{array}$} & Good work-area design & Ordinal Scale \\
\hline & & $\begin{array}{l}\text { Takes a flexible approach to issues arising } \\
\text { between work and family }\end{array}$ & Ordinal Scale \\
\hline & & Communicates effectively & Ordinal Scale \\
\hline \multirow{3}{*}{$\begin{array}{l}\text { Career } \\
\text { Education }\end{array}$} & \multirow{3}{*}{$\begin{array}{l}\text { Refers to the effort to stimulate, } \\
\text { motivate, and make the employees } \\
\text { understand their career } \\
\text { requirements }\end{array}$} & $\begin{array}{l}\text { Access to mentoring/ coaching } \\
\text { (Internal/External) }\end{array}$ & Ordinal Scale \\
\hline & & $\begin{array}{l}\text { Acknowledges when I have performed } \\
\text { well }\end{array}$ & Ordinal Scale \\
\hline & & $\begin{array}{l}\text { Provides me with the information I need to } \\
\text { do my job }\end{array}$ & Ordinal Scale \\
\hline \multirow{3}{*}{ Empowerment } & \multirow{3}{*}{$\begin{array}{l}\text { Empowerment in a nut shell is the } \\
\text { expansion of freedom of choice } \\
\text { and action }\end{array}$} & Demonstrating my skills and abilities & Ordinal Scale \\
\hline & & Having my ideas valued & Ordinal Scale \\
\hline & & $\begin{array}{l}\text { Allows me freedom to use my initiative in } \\
\text { performing my job }\end{array}$ & Ordinal Scale \\
\hline Individual & Refers the tendency of employees & I am prepared to move in to another & Ordinal Scale \\
\hline
\end{tabular}




\begin{tabular}{|c|c|c|c|}
\hline \multirow[t]{4}{*}{ Attitudes } & \multirow[t]{4}{*}{ to act in a particular way. } & geographical area to develop my career & \\
\hline & & I want to become an expert in my field & Ordinal Scale \\
\hline & & $\begin{array}{l}\text { I am prepared to move in to another work } \\
\text { area to develop my career }\end{array}$ & Ordinal Scale \\
\hline & & $\begin{array}{l}\text { I know and value my personality type and } \\
\text { work style }\end{array}$ & Ordinal Scale \\
\hline \multirow{3}{*}{$\begin{array}{l}\text { Individual } \\
\text { Career Mapping }\end{array}$} & \multirow{3}{*}{$\begin{array}{l}\text { The process to describe the career } \\
\text { prospects of an employee }\end{array}$} & I want to work in a higher level position & Ordinal Scale \\
\hline & & Gaining experience in a range of tasks & Ordinal Scale \\
\hline & & Acting in higher positions & Ordinal Scale \\
\hline \multirow{3}{*}{ Self-Appraisal } & \multirow{3}{*}{$\begin{array}{l}\text { Initial step of mapping out } \\
\text { employee's future, and gives an } \\
\text { opportunity for an employee to } \\
\text { review their career. }\end{array}$} & Feedback on my career development needs & Ordinal Scale \\
\hline & & $\begin{array}{l}\text { I am able to set goals consistent with } \\
\text { performance feedback I have received. }\end{array}$ & Ordinal Scale \\
\hline & & $\begin{array}{l}\text { I use specialized assessment processes or } \\
\text { tools to accommodate diversity }\end{array}$ & Ordinal Scale \\
\hline \multirow{3}{*}{$\begin{array}{l}\text { Career } \\
\text { Development }\end{array}$} & \multirow{3}{*}{$\begin{array}{l}\text { Refers developing an employee's } \\
\text { career by proper planning, and by } \\
\text { using proper tools, }\end{array}$} & $\begin{array}{l}\text { Currently I'm satisfied with the given } \\
\text { career development opportunities by SBK }\end{array}$ & Ordinal Scale \\
\hline & & $\begin{array}{l}\text { I'm recommending SBK as a place for } \\
\text { outside candidates grow in career. }\end{array}$ & Ordinal Scale \\
\hline & & $\begin{array}{l}\text { I'm satisfied with the current career } \\
\text { development policies of SBK }\end{array}$ & Ordinal Scale \\
\hline
\end{tabular}

Source: Author's Work, (2016) 